Supporting Information for:

\title{
Magnetic Exchange Coupling in Chloride-Bridged 5f-3d Heterometallic Complexes Generated via Insertion into a Uranium(IV) Dimethylpyrazolate Dimer
}

\author{
Stosh A. Kozimor, Bart M. Bartlett, Jeffrey D. Rinehart, and Jeffrey R. Long* \\ Department of Chemistry, University of California, Berkley, California 94720-1460
}

J. Am. Chem. Soc.

*E-mail: jrlong@berkeley.edu 


\section{Experimental Section}

General Considerations. The syntheses and manipulations of the extremely air and moisture sensitive compounds described below were conducted under nitrogen with rigorous exclusion of air and water by Schlenk and glovebox techniques. THF was distilled over sodium and benzophenone. Toluene, hexanes, dichloromethane, and acetonitrile were saturated with $\mathrm{N}_{2}$, passed through an activated alumina column, degassed by three freeze-pump-thaw cycles, and were stored under $\mathrm{N}_{2}$ over $3 \AA$ molecular sieves. Toluene- $d_{8}$ and $\mathrm{C}_{6} \mathrm{D}_{6}$ (Cambridge Isotope Laboratories) were distilled over $\mathrm{NaK}$ alloy and benzophenone and degassed by three freezepump-thaw cycles. Methanol was distilled over $\mathrm{Mg}$ and $\mathrm{I}_{2}$ and saturated with $\mathrm{N}_{2}$. Cyclam was dried under vacuum $\left(10^{-3}\right.$ Torr) for $24 \mathrm{~h}$ before use. The compound $\mathrm{Me}_{2} \mathrm{PzH}$ (Aldrich) was sublimed under vacuum $\left(10^{-3}\right.$ Torr) at $70{ }^{\circ} \mathrm{C}$ before use. The compound $\mathrm{KN}\left(\mathrm{SiMe}_{3}\right)_{2}$ (Aldrich) was used as received. $\mathrm{UCl}_{4}{ }^{\mathrm{S} 1}$ was prepared as previously described. The compound (cyclam) $\mathrm{NiCl}_{2}$ was prepared with a slight modification to the previously described procedure, ${ }^{\mathrm{S} 2}$ in that its synthesis was conducted under nitrogen and prepared from anhydrous $\mathrm{NiCl}_{2}$ in dry $\mathrm{MeOH}$. The compound (cyclam) $\mathrm{CuCl}_{2}$ was synthesized by modifying the previously published procedure, ${ }^{\mathrm{S} 3}$ in that anhydrous $\mathrm{CuCl}_{2}(100 \mathrm{mg}, 0.744 \mathrm{mmol})$ was reacted with cyclam $(149 \mathrm{mg}$, $0.744 \mathrm{mmol}$ ) in dry $\mathrm{MeOH}$ under a nitrogen atmosphere for $24 \mathrm{~h}$ at $50{ }^{\circ} \mathrm{C}$. The mixture was filtered, concentrated, and cooled to $-25{ }^{\circ} \mathrm{C}$ to afford (cyclam) $\mathrm{CuCl}_{2}$ as dark purple crystals (46 $\mathrm{mg}, 18 \%$ crystalline yield). The compound (cyclam) $\mathrm{ZnCl}_{2}$ was prepared similar to the previous reported procedure ${ }^{\mathrm{S} 4}$ by reacting cyclam (490 mg, $2.45 \mathrm{mmol}$ ) with $\mathrm{ZnCl}_{2}$ (344 mg, $2.53 \mathrm{mmol}$ ) at $65{ }^{\circ} \mathrm{C}$ in dry $\mathrm{MeOH}(10 \mathrm{~mL})$ for 12 hours under $\mathrm{N}_{2}$. The suspension was filtered, the solvent removed under vacuum, and the solid was washed with toluene. The solid was dissolved in hot $\mathrm{CH}_{2} \mathrm{Cl}_{2}$ and cooled to $-25{ }^{\circ} \mathrm{C}$ to afford (cyclam) $\mathrm{ZnCl}_{2}$ (427 mg, 51\% crystalline yield) as white crystals. The unit cell parameters and ${ }^{1} \mathrm{H}$ NMR spectra were consistent with those previously reported. ${ }^{\mathrm{S} 3, \mathrm{~S} 4} \mathrm{NMR}$ experiments were conducted with Bruker 300, 400, and $500 \mathrm{MHz}$ spectrometers. IR samples were analyzed as $\mathrm{KBr}$ pellets and recorded on a Nicolet Avatar 360 FTIR spectrometer. UV/Vis absorption spectra were measured using quartz cuvettes equipped with Teflon sealable stop cocks and recorded on a Hewlett-Packard 8453 spectrophotometer. Elemental analyses were performed by the analytical laboratories at the University of California, Berkeley. 
$\mathbf{K M e}_{2} \mathbf{P z}$. Toluene $(200 \mathrm{~mL})$ was added to a Schlenk flask that was charged with $\mathrm{KN}\left(\mathrm{SiMe}_{3}\right)_{2}(14.8 \mathrm{~g}, 0.0743 \mathrm{~mol})$ and $\mathrm{Me}_{2} \mathrm{PzH}(6.82 \mathrm{~g}, 0.0709 \mathrm{mmol})$ and the reaction was stirred for $24 \mathrm{~h}$. The white precipitate was separated from the solution by Schlenk filtration and washed three times with toluene. The solid was then washed with hexane, dried under vacuum at $70{ }^{\circ} \mathrm{C}$ for $3 \mathrm{~h}$, and $\mathrm{KMe}_{2} \mathrm{Pz}(9.45 \mathrm{~g}, 99 \%)$ was isolated as a white solid. IR: 3099s, 2971s, 2923s, 2861s, 2722w, 1696w, 1502s, 1431s, 1392s, 1308s, 1123w, 1067w, 1029s, 1008s, 964s, 756s, $730 \mathrm{~s}, 662 \mathrm{~m}, 587 \mathrm{w} \mathrm{cm}^{-1}$. Anal. Calc. for $\mathrm{C}_{5} \mathrm{H}_{7} \mathrm{KN}_{2}: \mathrm{C}, 44.75 ; \mathrm{H}, 5.22 ; \mathrm{N}, 20.88 \%$. Found: C. 44.40; H, 5.16; N, $20.77 \%$.

[U(Me $\left.\left.{ }_{2} \mathbf{P z}\right)_{4}\right]_{2}$. A green solution of $\mathrm{UCl}_{4}{ }^{\mathrm{S} 1}(0.693 \mathrm{~g}, 1.83 \mathrm{mmol})$ in THF $(5 \mathrm{~mL})$ was added dropwise to a flask that contained a stirring suspension of $\mathrm{KMe}_{2} \mathrm{Pz}(0.981 \mathrm{~g}, 7.31 \mathrm{mmol})$ and THF $(15 \mathrm{~mL})$ and the color changed to brown and then to green. After the mixture was stirred for $24 \mathrm{~h}$, a gelatinous brown solid was removed from the green solution by filtration through nylon supported filter paper with $0.22 \mu \mathrm{m}$ pores, and the solvent was removed under reduced pressure $\left(10^{-3}\right.$ Torr). Toluene was added to the resulting green solid and a brown toluene-insoluble solid, which was later found to contain $\mathrm{K}\left[\mathrm{U}\left(\mathrm{Me}_{2} \mathrm{Pz}\right)_{5}\right] \cdot \mathrm{THF}$, was separated by filtration and stored in a separate vial (see below). The solvent was removed from the green filtrate under vacuum and the toluene extraction was repeated twice. Dichloromethane was added to the green solid, the solution was filtered through Celite, and, upon removal of the solvent under reduced pressure, $1.01 \mathrm{~g}(89 \%)$ of product was isolated as a green microcrystalline solid. X-ray quality crystals of $\left[\mathrm{U}\left(\mathrm{Me}_{2} \mathrm{Pz}\right)_{4}\right]_{2}$ formed over the course of 3 days from concentrated solutions of toluene cooled to $-25{ }^{\circ} \mathrm{C}$. ${ }^{1} \mathrm{H}$ NMR $\left(\mathrm{C}_{6} \mathrm{D}_{6}, 298 \mathrm{~K}\right): \delta 2.5$ (s, $48 \mathrm{H}$, $\left.M e_{2} \mathrm{Pz}, \Delta v_{1 / 2}=500 \mathrm{~Hz}\right), 10.8\left(\mathrm{~s}, 8 \mathrm{H}, \mathrm{CH}-\mathrm{Me}_{2} \mathrm{Pz}, \Delta v_{1 / 2}=700 \mathrm{~Hz}\right) \mathrm{ppm} ;\left(\mathrm{CDCl}_{3}, 294 \mathrm{~K}\right) \delta 4.6(\mathrm{~s}$, $48 \mathrm{H}, \mathrm{Me}_{2} \mathrm{Pz}, \Delta v_{1 / 2}=580 \mathrm{~Hz}$ ), $11.6\left(\mathrm{~s}, 8 \mathrm{H}, \mathrm{CH}-\mathrm{Me}_{2} \mathrm{Pz}, \Delta v_{1 / 2}=1000 \mathrm{~Hz}\right.$ ) ppm (toluene- $d_{8}, 350.2$ K) $\delta 4.2\left(\mathrm{~s}, 48 \mathrm{H}, M e_{2} \mathrm{Pz}, \Delta v_{1 / 2}=78 \mathrm{~Hz}\right), 12.4\left(\mathrm{~s}, 8 \mathrm{H}, \mathrm{CH}-\mathrm{Me}_{2} \mathrm{Pz}, \Delta v_{1 / 2}=86 \mathrm{~Hz}\right) ;(292.2 \mathrm{~K}) \delta 5.7$ (s, $\left.48 \mathrm{H}, M e_{2} \mathrm{Pz}, \Delta v_{1 / 2}=1400 \mathrm{~Hz}\right), 14.2\left(\mathrm{~s}, 8 \mathrm{H}, \mathrm{CH}-\mathrm{Me}_{2} \mathrm{Pz}, \Delta v_{1 / 2}=1100 \mathrm{~Hz}\right) ;(270.2 \mathrm{~K}) \delta 8.5(\mathrm{br}$, s, $\left.M e_{2} \mathrm{Pz}\right), 3.6$ (bs, s, $\left.M e_{2} \mathrm{Pz}\right) ;(210 \mathrm{~K}) 14.5$ (s, $\left.M e_{2} \mathrm{Pz}, \Delta v_{1 / 2}=3300 \mathrm{~Hz}\right)$ ppm. IR: $3200 \mathrm{w}, 3105 \mathrm{~m}$, 2976w, 2946s, 2921s, 2871s, 2802m, 2721w, 1569m, 1516s, 1432s, 1365s, 1306s, 1277m, $1153 \mathrm{w}, 1105 \mathrm{~m}, 1080 \mathrm{~m}, 1054 \mathrm{~m}, 1006 \mathrm{~s}, 957 \mathrm{~s}, 922 \mathrm{w}, 867 \mathrm{~m}, 781 \mathrm{~s}, 730 \mathrm{~s}, 697 \mathrm{w} 650 \mathrm{w}, 586 \mathrm{w} \mathrm{cm}{ }^{-1}$. Absorption spectrum $\left(\mathrm{CH}_{2} \mathrm{Cl}_{2}\right): \lambda_{\max } 330$ (sh), 479 (sh), 505 (sh), 557, 620, 676, 823 (sh), 869 (sh), $944(\mathrm{sh}), 1005(\mathrm{sh}) \mathrm{nm}$. No extinction coefficients are reported since the degree of oligomerization in solution is unclear. Anal. Calcd. for $\mathrm{C}_{40} \mathrm{H}_{56} \mathrm{~N}_{16} \mathrm{U}_{2} \cdot{ }_{1}{ }_{2}\left(\mathrm{C}_{7} \mathrm{H}_{8}\right)$ : C, 40.07; H, 4.67; N, 17.47. Found: C, 39.87; H, 4.46; N, 17.06 . 
$\mathbf{K}\left[\mathbf{U}\left(\mathbf{M e}_{2} \mathbf{P z}\right)_{5}\right] \cdot \mathbf{T H F}$. The brown solid that was separated from the toluene extractions in the above synthesis of $\left[\mathrm{U}\left(\mathrm{Me}_{2} \mathrm{Pz}\right)_{4}\right]_{2}$ was washed three times with toluene and dissolved in THF. The solution was cooled to $-25{ }^{\circ} \mathrm{C}$ and after 3 days crystals formed. The mother liquor was decanted, and the crystals were dried under reduced pressure to give $18 \mathrm{mg}(1 \%)$ of product. Single crystals were grown from saturated solutions of THF at $-25^{\circ} \mathrm{C} . \mathrm{IR}_{n}: 3202 \mathrm{~s}, 3131 \mathrm{~s}, 3109 \mathrm{~s}$, 3039s, 2921s, 2878s, 2792s, 2726m, 2609w, 1672w, 1596m, 1577m,1517s, 1484s, 1459s, 1418s, $1372 \mathrm{~m}, 1307 \mathrm{~s}, 1265 \mathrm{w}, 1155 \mathrm{w}, 1149 \mathrm{w}, 1100 \mathrm{~m}, 1029 \mathrm{~s}, 1010 \mathrm{~s}, 963 \mathrm{~m}, 854 \mathrm{~m}, 780 \mathrm{~s}, 738 \mathrm{~m}, 730 \mathrm{~m}$, $683 \mathrm{w}, 662 \mathrm{~m}, 553 \mathrm{~m} \mathrm{~cm}^{-1}$. Anal. Calcd. for $\mathrm{C}_{29} \mathrm{H}_{43} \mathrm{~N}_{10} \mathrm{UKO}$ : C, 42.24; H, 5.22; N, $16.99 \%$. Found: C, 41.88; H, 5.14; N, $16.86 \%$.

$\left(\mathbf{M e}_{2} \mathbf{P z}\right)_{4} \mathbf{U}$ (THF). THF $(1 \mathrm{~mL})$ was added to a flask that contained $\left[\mathrm{U}\left(\mathrm{Me}_{2} \mathrm{Pz}\right)_{4}\right]_{2}(499$ $\mathrm{mg}, 0.404 \mathrm{mmol}$ ) and the solution was filtered. The solution was cooled to $-25^{\circ} \mathrm{C}$ and after 10 days crystals formed. The solution was decanted from the crystals, they were dried under vacuum, and $\left(\mathrm{Me}_{2} \mathrm{Pz}\right)_{4} \mathrm{U}(\mathrm{THF})$ was isolated $(180 \mathrm{mg}, 32 \%)$ in crystalline form. X-ray quality crystals can be grown from a saturated solution of $\left[\mathrm{U}\left(\mathrm{Me}_{2} \mathrm{Pz}\right)_{4}\right]_{2}$ in THF at $-25{ }^{\circ} \mathrm{C}$. ${ }^{1} \mathrm{H}$ NMR (THF- $H_{8}$ referenced to an internal standard of $\mathrm{C}_{6} \mathrm{D}_{6}, 298 \mathrm{~K}$ ): $\delta 6.9$ (s, $24 \mathrm{H}, \mathrm{Me}_{3} \mathrm{Pz}, \Delta v_{1 / 2}=320$ $\mathrm{Hz}), 14.2$, (s, $\left.4 \mathrm{H}, \mathrm{CH}-\mathrm{Me}_{2} \mathrm{Pz}, \Delta v_{1 / 2}=1000 \mathrm{~Hz}\right) \mathrm{ppm}$. No resonances attributable to the coordinated THF ligand were identified. IR: $3201 \mathrm{w}, 3102 \mathrm{~m}, 2978 \mathrm{~s}, 2951 \mathrm{~s}, 2922 \mathrm{~s}, 2800 \mathrm{~s}$, $2723 \mathrm{w}, 1569 \mathrm{~m}, 1514 \mathrm{~s}, 1456 \mathrm{~s}, 1412 \mathrm{~s}, 1365 \mathrm{~s}, 1307 \mathrm{~m}, 1276 \mathrm{~m}, 1170 \mathrm{w}, 1153 \mathrm{w}, 1105 \mathrm{~m}, 1054 \mathrm{~m}$, $1024 \mathrm{~s}, 1007 \mathrm{~s}, 958 \mathrm{~s}, 922 \mathrm{~m}, 867 \mathrm{~s}, 808 \mathrm{~s}, 781 \mathrm{~s}, 730 \mathrm{~s}, 673 \mathrm{w}, 651 \mathrm{w} \mathrm{cm} \mathrm{cm}^{-1}$. Absorption spectrum $\left(\mathrm{CH}_{2} \mathrm{Cl}_{2}\right): \lambda_{\max }\left(\varepsilon_{\mathrm{M}}\right) 320$ (2994), 439 (39), 472 (23), 511 (19), 557 (11), 572 (10), 612 (23), 631 (sh, 18), 673 (32), 808 (7), 867 (11), 925 (sh, 16), 979 (sh, 25) 1039 (39 $\left.\mathrm{Lmol}^{-1} \mathrm{~cm}^{-1}\right)$. Anal. Calcd. for $\mathrm{C}_{24} \mathrm{H}_{36} \mathrm{~N}_{16} \mathrm{OU}: \mathrm{C}, 41.75 ; \mathrm{H}, 5.21 ; \mathrm{N}, 16.15 \%$. Found: $\mathrm{C}, 41.71 ; \mathrm{H}, 5.30 ; \mathrm{N}, 16.15 \%$.

(cyclam) $\mathbf{N i}\left[(\mu-\mathrm{Cl}) \mathrm{U}\left(\mathrm{Me}_{2} \mathrm{Pz}\right)_{4}\right]_{2}\left(\mathrm{NiU}_{2}\right)$. A green solution of $\left[\mathrm{U}\left(\mathrm{Me}_{2} \mathrm{Pz}\right)_{4}\right]_{2}(752 \mathrm{mg}$, $0.608 \mathrm{mmol})$ in $\mathrm{CH}_{2} \mathrm{Cl}_{2}(5 \mathrm{~mL})$ was added dropwise to a flask charged with a pink suspension of (cyclam) $\mathrm{NiCl}_{2}(200 \mathrm{mg}, 0.607 \mathrm{mmol})$ in $\mathrm{CH}_{2} \mathrm{Cl}_{2}(5 \mathrm{~mL})$. Everything immediately dissolved and the resulting green solution was stirred for $12 \mathrm{~h}$. The solution was filtered through Celite, concentrated under vacuum to approximately $1 \mathrm{~mL}$, and cooled to $-25{ }^{\circ} \mathrm{C}$. After $48 \mathrm{~h}$, the solvent was decanted from the crystals that had formed. The crystals were dried under vacuum, to give $618 \mathrm{mg}(65 \%)$ of product. X-ray quality crystals readily form from concentrated solution of $\mathrm{CH}_{2} \mathrm{Cl}_{2}$ cooled to $-25{ }^{\circ} \mathrm{C}$. ${ }^{1} \mathrm{H}$ NMR $\left(\mathrm{C}_{6} \mathrm{D}_{6}, 294 \mathrm{~K}\right): \delta-18.3\left(\mathrm{~s}, 4, \mathrm{C}_{10} \mathrm{H}_{24} \mathrm{~N}_{4}, \Delta v_{1 / 2}=160 \mathrm{~Hz}\right)-$ $9.1\left(\mathrm{~s}, 4, \mathrm{C}_{10} \mathrm{H}_{24} \mathrm{~N}_{4}, \Delta v_{1 / 2}=380 \mathrm{~Hz}\right), 6.1$ (s, 48, $\left.M e_{2} \mathrm{Pz}, \Delta v_{1 / 2}=840 \mathrm{~Hz}\right) 15.6$ (s, 8, HC-Me $2 \mathrm{Pz}$ $\left.\mathrm{C}_{3} \mathrm{~N}_{2}, \Delta v_{1 / 2}=870 \mathrm{~Hz}\right), 41\left(\mathrm{~s}, 8, \mathrm{C}_{10} \mathrm{H}_{24} \mathrm{~N}_{4}, \Delta v_{1 / 2}=870 \mathrm{~Hz}\right), 178\left(\mathrm{~s}, 8, \mathrm{C}_{10} \mathrm{H}_{24} \mathrm{~N}_{4}, \Delta v_{1 / 2}=670 \mathrm{~Hz}\right)$ 
ppm; (toluene- $\left.d_{8}, 323.1 \mathrm{~K}\right): \delta-16.4\left(\mathrm{~s}, 4, \mathrm{C}_{10} \mathrm{H}_{24} \mathrm{~N}_{4}, \Delta v_{1 / 2}=130 \mathrm{~Hz}\right)-7.7\left(\mathrm{~s}, 4, \mathrm{C}_{10} \mathrm{H}_{24} \mathrm{~N}_{4}, \Delta v_{1 / 2}=\right.$ $300 \mathrm{~Hz}$ ), 5.3 (s, 48, Me $\left.2 \mathrm{Pz}, \Delta v_{1 / 2}=320 \mathrm{~Hz}\right), 14.4$ (s, 8, CH-Me $\left.2 \mathrm{Pz}, \Delta v_{1 / 2}=320 \mathrm{~Hz}\right), 36.7(\mathrm{~s}, 8$, $\left.\mathrm{C}_{10} \mathrm{H}_{24} \mathrm{~N}_{4}, \Delta v_{1 / 2}=1020 \mathrm{~Hz}\right) 161\left(\mathrm{~s}, 8, \mathrm{C}_{10} \mathrm{H}_{24} \mathrm{~N}_{4}, \Delta v_{1 / 2}=670 \mathrm{~Hz}\right) \mathrm{ppm}$; (toluene- $\left.d_{8}, 193.1 \mathrm{~K}\right): \delta$ $32.2\left(\mathrm{~s}, 4, \mathrm{C}_{10} \mathrm{H}_{24} \mathrm{~N}_{4}, \Delta \mathrm{v}_{1 / 2}=420 \mathrm{~Hz}\right),-19.1\left(\mathrm{~s}, 12, M e_{2} \mathrm{Pz}-\mathrm{axial}, \Delta \mathrm{v}_{1 / 2}=480 \mathrm{~Hz}\right),-13.2(\mathrm{~s}$, $\mathrm{C}_{10} \mathrm{H}_{24} \mathrm{~N}_{4}, 4, \Delta v_{1 / 2}=480 \mathrm{~Hz}$ ), -16.7 (s, 2, CH-Me ${ }_{2} \mathrm{Pz}$-axial), 20.0 (s, 36, Me 2 Pz-equatorial, $\Delta v_{1 / 2}$ $=220 \mathrm{~Hz}), 33.1\left(\mathrm{~s}, 6, \mathrm{CH}-\mathrm{Me}_{2} \mathrm{Pz}, \Delta v_{1 / 2}=160 \mathrm{~Hz}\right), 54.2\left(\mathrm{~s}, 8, \mathrm{C}_{10} \mathrm{H}_{24} \mathrm{~N}_{4}, \Delta v_{1 / 2}=1830 \mathrm{~Hz}\right) 280(\mathrm{~s}$, $\left.8, \mathrm{C}_{10} \mathrm{H}_{24} \mathrm{~N}_{4}, \Delta v_{1 / 2}=1300 \mathrm{~Hz}\right)$ ppm. IR: 3265m, 3251s, 3227s, 3137m, 3099m, 3025m, 2954s, 2921s, 2862s, 2803m, 2721w, 1570m, 1520s, 1452s, 1437s, 1374s, 1365s, 1345m, 1334m, $1309 \mathrm{~m}, 1289 \mathrm{w}, 1262 \mathrm{~m}, 1240 \mathrm{~m}, 1153 \mathrm{w}, 1101 \mathrm{~s}, 1077 \mathrm{~m}, 1061 \mathrm{~m}, 1029 \mathrm{~s}, 1006 \mathrm{~s}, 960 \mathrm{~s}, 943 \mathrm{~s}, 877 \mathrm{~s}$, $783 \mathrm{~s}, 742 \mathrm{~m}, 730 \mathrm{~s}, 672 \mathrm{w}, 651 \mathrm{w}, 585 \mathrm{~m}, 547 \mathrm{~m} \mathrm{~cm}^{-1}$. Absorption spectrum $\left(\mathrm{CH}_{2} \mathrm{Cl}_{2}\right): \lambda_{\max }\left(\varepsilon_{\mathrm{M}}\right)$ 441 (129), 479 (81), 511 (62), 532 (49), 561 (sh, 33), 625 (51), 660 (sh, 61), 677 (92), 721 (19),

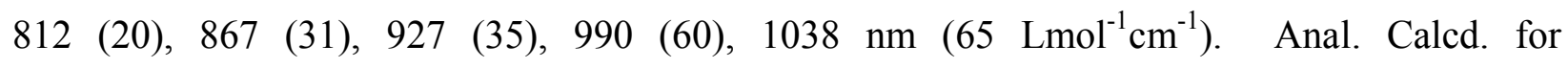
$\mathrm{C}_{50} \mathrm{H}_{80} \mathrm{Cl}_{2} \mathrm{~N}_{20} \mathrm{NiU}_{2}$ : C, 38.34; H, 5.10; N, $17.89 \%$. Found: C, 37.99; H, 5.16; N, $17.58 \%$.

(cyclam) $\mathrm{Cu}\left[(\boldsymbol{\mu}-\mathrm{Cl}) \mathrm{U}\left(\mathrm{Me}_{2} \mathbf{P z}\right)_{4}\right]_{2}\left(\mathrm{CuU}_{2}\right)$. In a procedure analogous to that described above for (cyclam) $\mathrm{Ni}\left[(\mu-\mathrm{Cl}) \mathrm{U}\left(\mathrm{Me}_{2} \mathrm{Pz}\right)_{4}\right]_{2}$, $\left[\mathrm{U}\left(\mathrm{Me}_{2} \mathrm{Pz}\right)_{4}\right]_{2}(787 \mathrm{mg}, 0.636 \mathrm{mmol})$ was reacted with (cyclam) $\mathrm{CuCl}_{2}(213 \mathrm{mg}, 0.636 \mathrm{mmol})$. The product was isolated as purple crystals $(616 \mathrm{mg}$, $62 \%$ ) after the solution was filtered, concentrated, and cooled to $-25{ }^{\circ} \mathrm{C}$ for $48 \mathrm{~h}$. ${ }^{1} \mathrm{H}$ NMR $\left(\mathrm{CH}_{2} \mathrm{Cl}_{2}\right.$ referenced to a $\mathrm{C}_{6} \mathrm{D}_{6}$ internal standard, $\left.298 \mathrm{~K}\right): \delta 6.8\left(\Delta v_{1 / 2}=670 \mathrm{~Hz}\right) 15.6\left(\Delta v_{1 / 2}=\right.$ $1000 \mathrm{~Hz}$ ) ppm. IR: 3369m 3217s 3135s 3100s 3021m 2921s 2871s 2798m 2721w 1574m 1519s 1432s 1365s 1308m 1242w 1154w 1100s 1066s 1029s 1007s 976s 887m 781s 730s 651w 585w

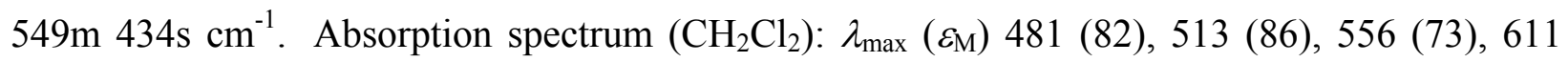

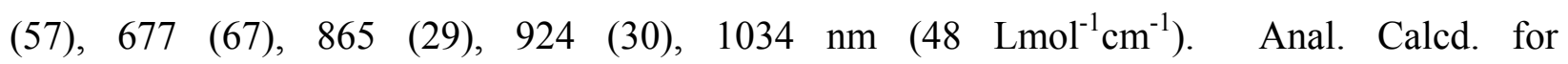
$\mathrm{C}_{50} \mathrm{H}_{80} \mathrm{Cl}_{2} \mathrm{CuN}_{20} \mathrm{U}_{2}$ : C, 38.20; H, 5.14; N, 17.83\%. Found: C, 38.04; H, 5.07; N, 17.66\%.

(cyclam)Zn $\left[(\boldsymbol{\mu}-\mathbf{C l}) \mathbf{U}\left(\mathbf{M e}_{2} \mathbf{P z}\right)_{4}\right]_{\mathbf{2}}\left(\mathbf{Z n U}_{2}\right)$. In a procedure analogous to that described above for (cyclam) Ni $\left[(\mu-\mathrm{Cl}) \mathrm{U}\left(\mathrm{Me}_{2} \mathrm{Pz}\right)_{4}\right]_{2}$, $\left[\mathrm{U}\left(\mathrm{Me}_{2} \mathrm{Pz}\right)_{4}\right]_{2}(638 \mathrm{mg}, 0.516 \mathrm{mmol})$ was reacted with (cyclam) $\mathrm{ZnCl}_{2}(168 \mathrm{mg}, 0.516 \mathrm{mmol})$ to form a green solution from which the product was isolated as green crystals (408 mg, 50\%). X-ray quality crystals readily form from concentrated solution of $\mathrm{CH}_{2} \mathrm{Cl}_{2}$ cooled to $-25{ }^{\circ} \mathrm{C}$. ${ }^{1} \mathrm{H} \mathrm{NMR}\left(\mathrm{C}_{6} \mathrm{D}_{6}, 294 \mathrm{~K}\right): \delta-26\left(\mathrm{~s}, 4, \mathrm{C}_{10} H_{24} \mathrm{~N}_{4}, \Delta v_{1 / 2}=200\right.$ $\mathrm{Hz}),-4.0\left(\mathrm{~s}, 4, \mathrm{C}_{10} H_{24} \mathrm{~N}_{4}, \Delta v_{1 / 2}=300 \mathrm{~Hz}\right)-1.5\left(\mathrm{~s}, 12, \mathrm{C}_{10} \mathrm{H}_{24} \mathrm{~N}_{4}, \Delta v_{1 / 2}=180 \mathrm{~Hz}\right), 6.9(\mathrm{~s}, 48$, $\left.M e_{2} \mathrm{Pz}, \Delta v_{1 / 2}=800 \mathrm{~Hz}\right) 15.9\left(\mathrm{~s}, 4, \mathrm{CH}-\mathrm{Me}_{2} \mathrm{Pz}, \Delta v_{1 / 2}=1200 \mathrm{~Hz}\right) \mathrm{ppm}$. Only three signals attributable to the cyclam ligand were identifiable. IR (neat): 3245s, 3218, 3141m, 3101m, 2955s, 2922s, 2866s, 2798m, 2720w, 1573m, 1518s, 1461s, 1435s, 1373m, 1365m, 1348m, 
$1338 \mathrm{~m}, 1307 \mathrm{~m}, 1283 \mathrm{~m}, 1254 \mathrm{w}, 1241 \mathrm{~m}, 1154 \mathrm{w}, 1110 \mathrm{~s}, 1095 \mathrm{~s}, 1062 \mathrm{~m}, 1026 \mathrm{~m}, 1007 \mathrm{~s}, 967 \mathrm{~s}$, 946s, 893w, 878s, 841w, 786s (br), 730s, 672w, 651w, 586m, 556m, 433m cm $\mathrm{m}^{-1}$. Absorption spectrum $\left(\mathrm{CH}_{2} \mathrm{Cl}_{2}\right): \lambda_{\max }\left(\varepsilon_{\mathrm{M}}\right) 327$ (sh, 3537), 478 (sh, 86), 504 (sh, 64), 529 (sh, 38), 559 (30),

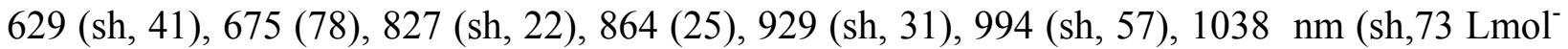
${ }^{1} \mathrm{~cm}^{-1}$ ). Anal. Calcd. for $\mathrm{C}_{50} \mathrm{H}_{80} \mathrm{Cl}_{2} \mathrm{~N}_{20} \mathrm{U}_{2} \mathrm{Zn}$ : C, 38.17; H, 5.81; N, $17.81 \%$. Found: C, 37.92; H, 5.34; N, $17.56 \%$.

Magnetic Measurements. Finely dispersed samples were prepared by first adding approximately $100 \mathrm{mg}$ of molten eicosane (Aldrich) to a $7 \mathrm{~mm}$ quartz tube. After the eicosane had cooled, crystals of the compounds $\mathrm{NiU}_{2}\left(95.5 \mathrm{mg}\right.$ ), $\mathrm{CuU}_{2}\left(93.8 \mathrm{mg}\right.$ ), and $\mathrm{ZnU}_{2}(105.8 \mathrm{mg}$ ), that had been desolvated under vacuum $\left(10^{-3}\right.$ Torr) to remove the $\mathrm{CH}_{2} \mathrm{Cl}_{2}$ solvate molecules, were loaded into the tube and embedded in the eicosane matrix to prevent crystallite torqueing at high magnetic fields. The total amounts of eicosane used were 288.6, 267.8, and $299.9 \mathrm{mg}$ for the samples of $\mathrm{NiU}_{2}, \mathrm{CuU}_{2}$, and $\mathrm{ZnU}_{2}$, respectively. Each tube was fitted with a Teflon sealable adapter, attached to a Schenk line, and flame sealed under vacuum.

Magnetic susceptibility measurements were collected using a Quantum Design MPMS2 SQUID magnetometer. DC susceptibility data measurements were performed at temperatures ranging from 5 to $301 \mathrm{~K}$, using applied fields of $0.1,0.5$, and $1 \mathrm{~T}$. Magnetization measurements were performed at temperatures ranging from 1.78 to $10 \mathrm{~K}$, using applied fields from 1 to $7 \mathrm{~T}$ at $1 \mathrm{~T}$ intervals.

Data for $\mathrm{NiU}_{2}, \mathrm{CuU}_{2}$, and $\mathrm{ZnU}_{2}$ were corrected for diamagnetic contributions from the sample holder and eicosane, as well as for the core diamagnetism of each sample. These last were estimated using Pascal's constants to give $\chi_{\mathrm{D}}=-7.75 \times 10^{-4},-7.74 \times 10^{-4}$, and $-7.48 \times 10^{-4}$ $\mathrm{emu} / \mathrm{mol}$ for $\mathrm{NiU}_{2}, \mathrm{CuU}_{2}$, and $\mathrm{ZnU}_{2}$, respectively. A temperature-independent paramagnetism value of 0.000825 cgsu was used for $\mathrm{NiU}_{2}$. 

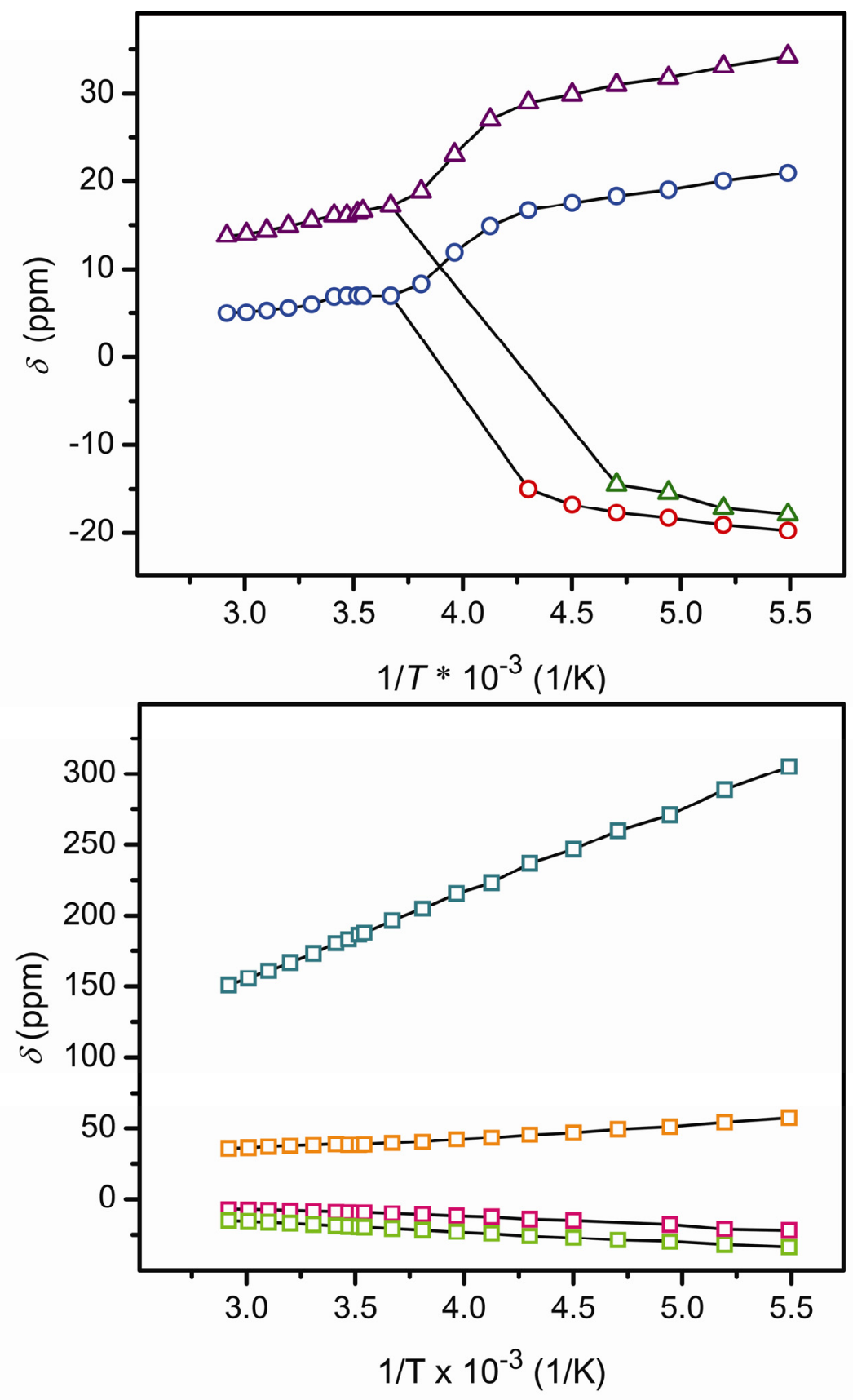

Figure S1. Variable-temperature ${ }^{1} \mathrm{H}$ NMR spectra of (cyclam) $\mathrm{Ni}\left[(\mu-\mathrm{Cl}) \mathrm{U}\left(\mathrm{Me}_{2} \mathrm{Pz}\right)_{4}\right]_{2}$ in $d^{8}$ toluene with the chemical shift (ppm) plotted against the inverse temperature multiplied by $10^{-3}$ $(1 / \mathrm{K})$. Upper: Resonances for the 1,3-dimethylpyrazolate: $(\triangle) \mathrm{CH}-\mathrm{Me}_{2} \mathrm{Pz},(\bigcirc) \mathrm{Me}_{2} \mathrm{Pz},(\triangle)$ axial- $\mathrm{CH}-\mathrm{Me}_{2} \mathrm{Pz},(\mathrm{O})$ axial- $\mathrm{Me}_{2} \mathrm{Pz}$. Lower: Resonances attributable to the cyclam ligand. 


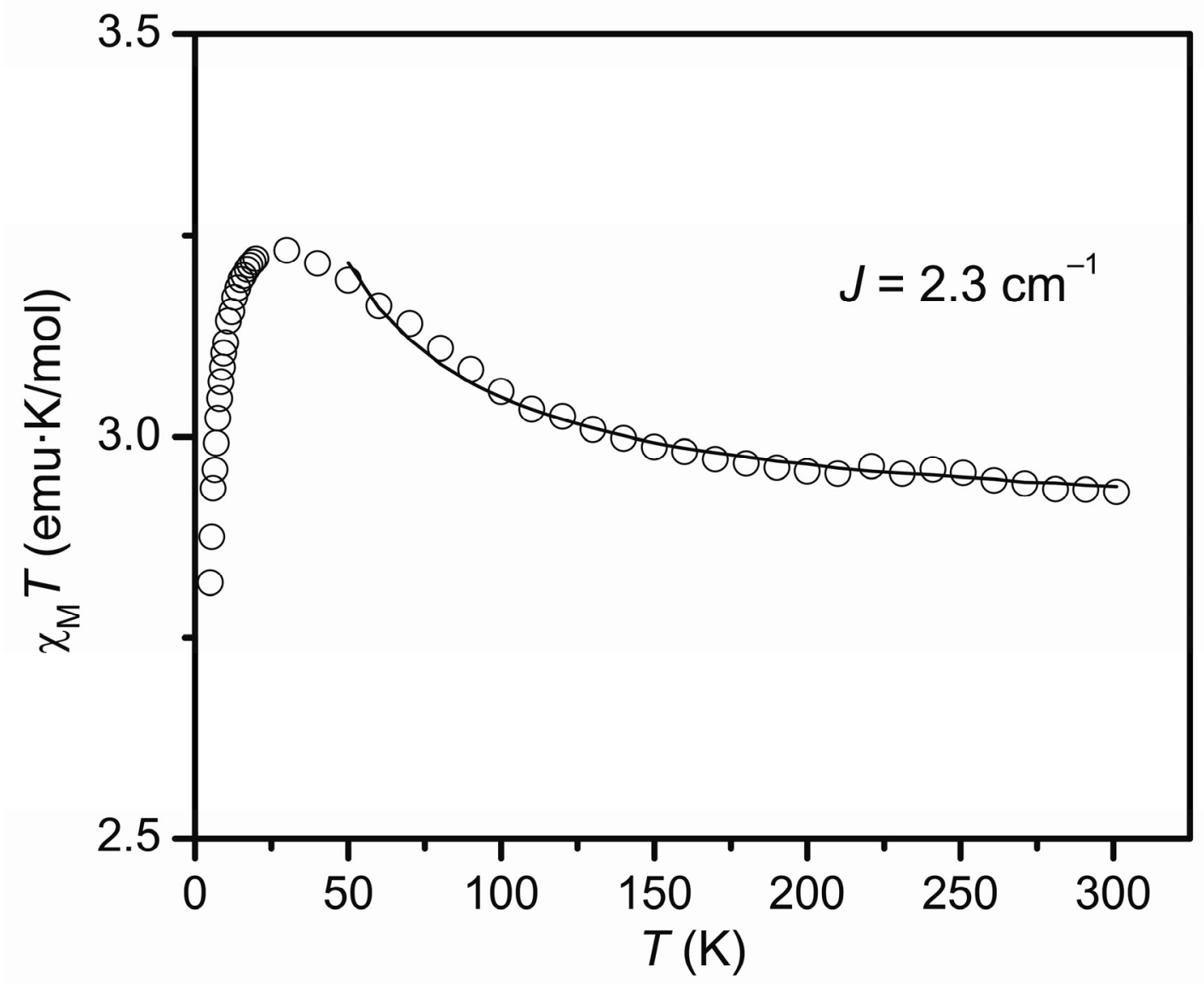

Figure S2. A plot of the spin-only modified $\chi_{\mathrm{M}} T$ data for (cyclam) $\mathrm{Ni}\left[(\mu-\mathrm{Cl}) \mathrm{U}\left(\mathrm{Me}_{2} \mathrm{Pz}\right)_{4}\right]_{2}$ vs. temperature. The solid line represents the calculated fit to the data; see text for details. The data shown were obtained by applying the following expression: $\chi_{M} T=\chi_{M} T\left(\mathrm{NiU}_{2}\right)-\chi_{\mathrm{M}} \mathrm{T}\left(\mathrm{ZnU}_{2}\right)+2$. 


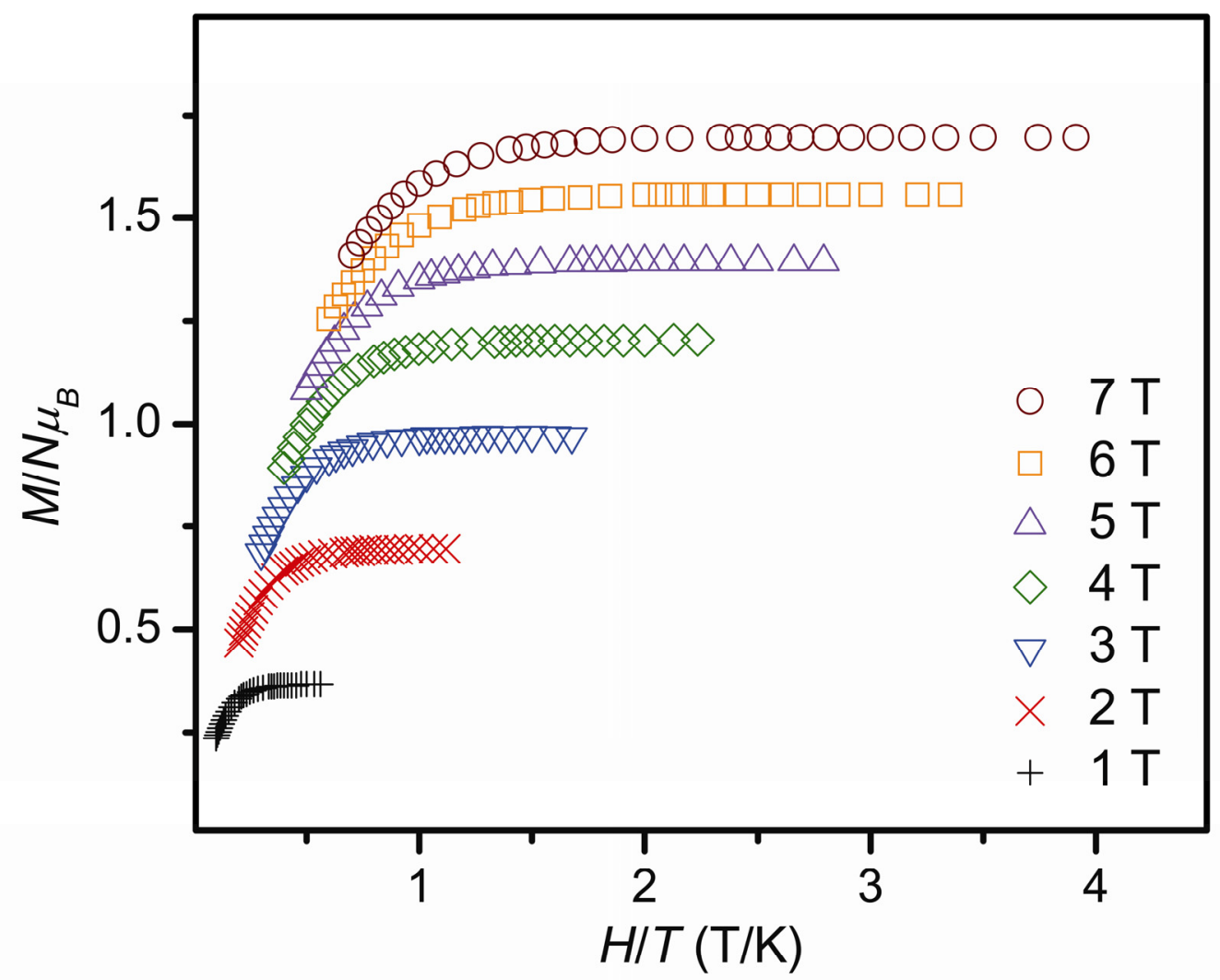

Figure S3. A plot of reduced magnetization, $M / N \mu_{\mathrm{B}}$ (where $N$ is Avogadro's number and $\mu_{\mathrm{B}}$ is the Bohr magneton) versus $H / T$ for (cyclam) $\mathrm{Ni}\left[(\mu-\mathrm{Cl}) \mathrm{U}\left(\mathrm{Me}_{2} \mathrm{Pz}\right)_{4}\right]_{2}$. Data were measured from 1.8 to $10 \mathrm{~K}$ and at the seven field strengths specified. 
Computational Details. The Amsterdam Density Functional (ADF) suite of programs (version 2006.01) ${ }^{\mathrm{S} 5}$ was used for all calculations. The Zeroeth Order Regular Approximation $(\text { ZORA })^{\mathrm{S} 6}$ to the Dirac Equation was implemented for scalar relativistic corrections and applied to all atomic basis sets. Uranium basis sets were constructed from triple- $\zeta$ quality Slater-type functions plus polarization. All other basis sets were constructed from triple- $\zeta$ quality Slatertype functions plus two polarization functions. The frozen core approximation was applied to $\mathrm{C}$ $(1 \mathrm{~s}), \mathrm{N}(1 \mathrm{~s}), \mathrm{Cl}(2 \mathrm{p})$, and $\mathrm{U}(5 \mathrm{~d})$. The exchange and correlation functional implemented was built from the Local Density Approximation of Vosko, Wilk, and Nusair ${ }^{\mathrm{S} 7}$ with the Generalized Gradient Approximation corrections of Perdew, Burke, and Ernzerhof. ${ }^{\mathrm{S} 8}$ Orbital visualizations were generated in ADFview.

$\mathrm{X}$-ray Data Collection, Structure Solution, and Refinement for $\left[\mathrm{U}\left(\mathrm{Me}_{2} \mathrm{Pz}\right)_{4}\right]_{2}$ -0.5PhMe. A green crystal of approximate dimensions $0.07 \times 0.09 \times 0.13 \mathrm{~mm}$ was mounted on a Kapton loop and transferred to a Brüker Apex diffractometer and cooled in a dinitrogen stream. The SMART ${ }^{\mathrm{S} 9}$ program package was used to determine the unit-cell parameters and for data collection (10 s/frame scan time for a hemisphere of diffraction data). The raw frame data was processed using $\mathrm{SAINT}^{\mathrm{S} 10}$ and $\mathrm{SADABS}{ }^{\mathrm{S} 11}$ to yield the reflection data file. Subsequent calculations were carried out using the SHELXTL ${ }^{\mathrm{S} 12}$ program. The diffraction symmetry was $P \overline{1}$ and the systematic absences were consistent with the triclinic space groups $P 1$ and $P \overline{1}$. It was later determined that the centrosymmetric space group $P \overline{1}$ was correct.

The structure was solved by direct methods and refined on $\mathrm{F}^{2}$ by full-matrix least-squares techniques. The analytical scattering factors ${ }^{\mathrm{S} 13}$ for neutral atoms were used throughout the analysis. Hydrogen atoms were included using a riding model. The toluene molecule that cocrystallized was disordered and atoms C(41), C(43), C(44), C(45), and C(46) were included with partial site-occupancy-factors $(1 / 2)$ to account for an equal distribution over two sites. At convergence, $w R_{2}=0.0992$ and Goof $=1.026$ for 547 variables refined against 8552 data. As a comparison for refinement on $F, R_{1}=0.0441$ for those 5928 data with $I>2.0 \sigma(I)$. 


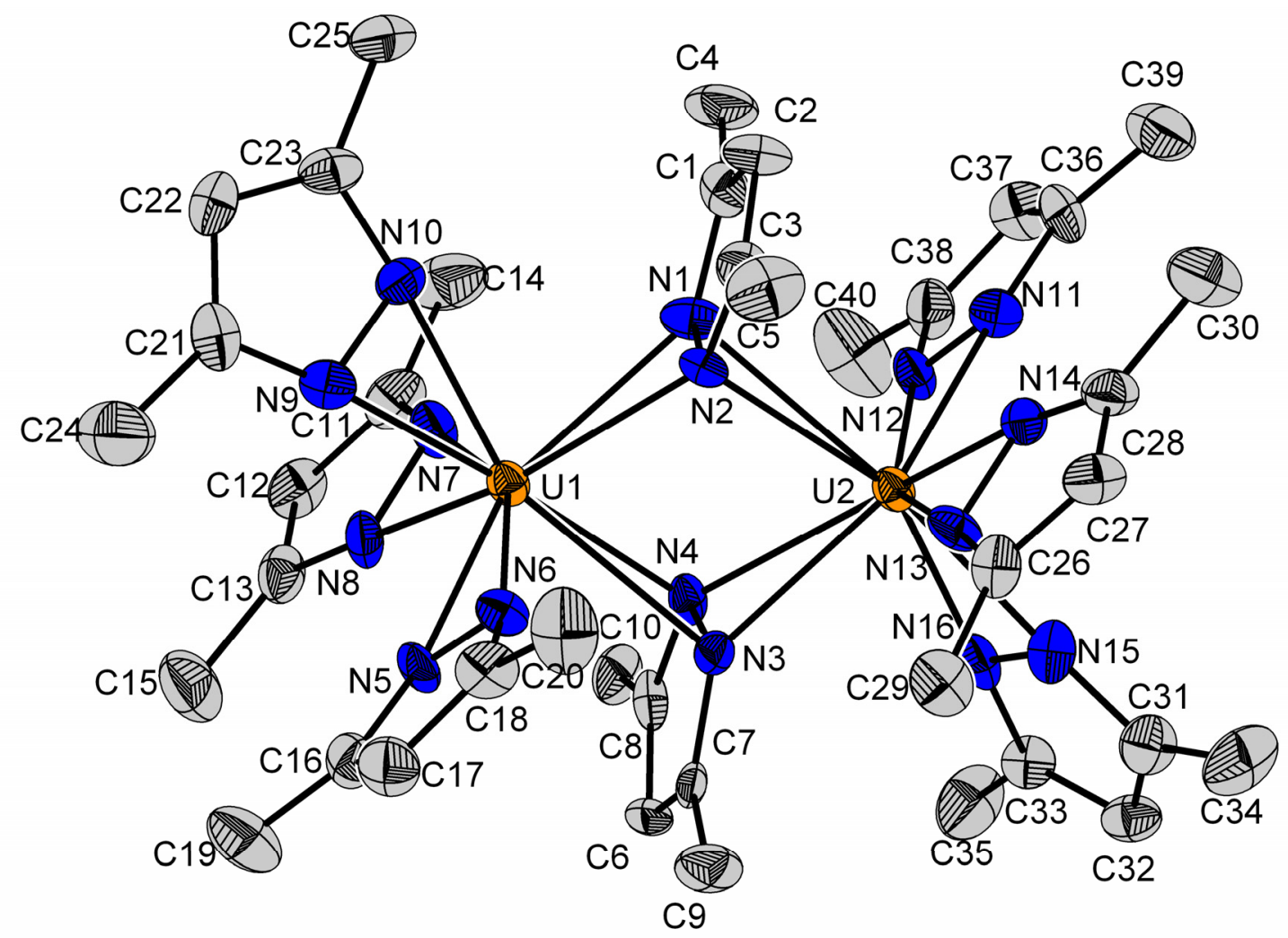

Figure S4. Structure of $\left[\mathrm{U}\left(\mathrm{Me}_{2} \mathrm{Pz}\right)_{4}\right]_{2}$ with ellipsoids drawn at the $50 \%$ probability level. Orange, grey, and blue ellipsoids represent U, C, and N atoms respectively; hydrogen atoms have been omitted for clarity. 


\section{X-ray Data Collection, Structure Determination, and Refinement for $\mathrm{K}\left[\mathrm{U}\left(\mathrm{Me}_{2} \mathrm{Pz}\right)_{5}\right]$}

-THF. A dark brown crystal of approximate dimensions $0.21 \times 0.10 \times 0.05 \mathrm{~mm}$ was mounted on a Kapton loop and transferred to a Brüker SMART diffractometer. The SMART ${ }^{\mathrm{S} 9}$ program package was used to determine the unit-cell parameters and for data collection $(25 \mathrm{sec} / \mathrm{frame}$ scan time for a a hemisphere of diffraction data). The raw frame data was processed using $\mathrm{SAINT}^{\mathrm{S} 10}$ and SADABS ${ }^{\mathrm{S} 11}$ to yield the reflection data file. Subsequent calculations were carried out using the SHELXTL ${ }^{\mathrm{S} 12}$ program. The diffraction symmetry was $P 2_{1} 2_{1} 2_{1}$ and the systematic absences were consistent with the orthorhombic space groups $P 2_{1} 2_{1} 2$ and $P 2_{1} 2_{1} 2_{1}$. It was later determined that the centrosymmetric space group $P 2_{1} 2_{1} 2_{l}$ was correct.

The structure was solved by direct methods and refined on $\mathrm{F}^{2}$ by full-matrix least-squares techniques. The analytical scattering factors ${ }^{\mathrm{S} 13}$ for neutral atoms were used throughout the analysis. Hydrogen atoms were included using a riding model. During refinement several carbon and nitrogen atoms became non-positive-definite. Only the uranium and potassium atoms were refined with anisotropic thermal parameters. The final least-squares analysis yielded wR2 $=0.1333$ and $\mathrm{Goof}=1.110$ for 536 variables refined against 19545 data. As a comparison for refinement on $\mathrm{F}, \mathrm{R} 1=0.0697$ for those 14420 data with $\mathrm{I}>2.0 \sigma(\mathrm{I})$.

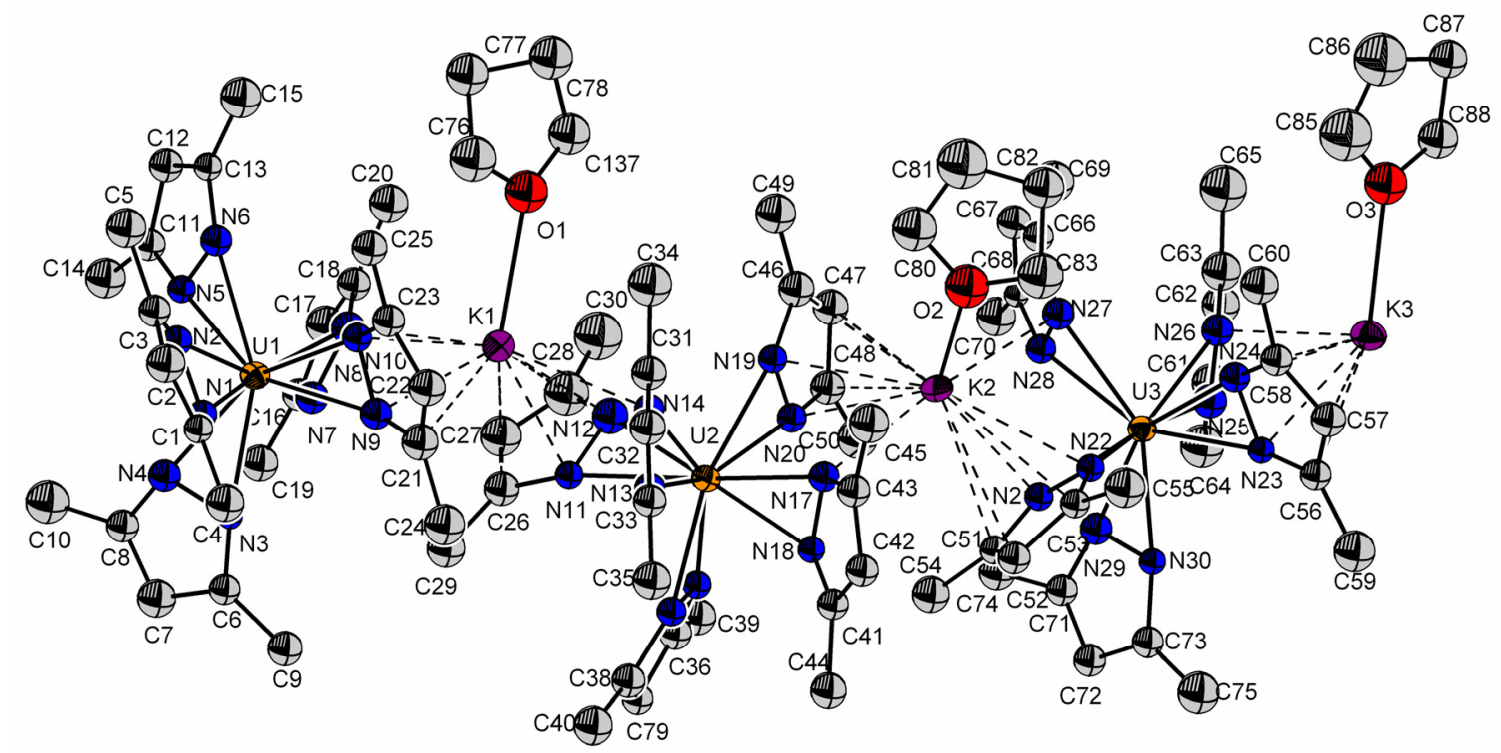

Figure S5. Structure of $\left[\mathrm{U}\left(\mathrm{Me}_{2} \mathrm{Pz}\right)_{5}\right]^{1-}$ complexes linked through $\mathrm{K}(\mathrm{THF})$ moeities, with ellipsoids drawn at the $50 \%$ level. Orange, purple, grey, blue, and red ellipsoids represent $\mathrm{U}, \mathrm{K}$, $\mathrm{C}, \mathrm{N}$, and $\mathrm{O}$ atoms respectively; $\mathrm{H}$ atoms are omitted for clarity. 
X-ray Data Collection, Structure Solution and Refinement for $\left(\mathrm{Me}_{2} \mathrm{Pz}\right)_{4} \mathrm{U}(\mathrm{THF})$. A green crystal of approximate dimensions $0.15 \times 0.08 \times 0.06 \mathrm{~mm}$ was mounted on a Kapton loop and transferred to a Brüker Apex diffractometer. The SMART ${ }^{\mathrm{S} 9}$ program package was used to determine the unit-cell parameters and for data collection $(20 \mathrm{~s} /$ frame scan time for a hemisphere of diffraction data). The raw frame data was processed using SAINT ${ }^{\mathrm{S} 10}$ and $\mathrm{SADABS}^{\mathrm{S} 11}$ to yield the reflection data file. Subsequent calculations were carried out using the SHELXTL ${ }^{\text {S12 }}$ program. The diffraction symmetry was $P 2_{1} / m$ and the systematic absences were consistent with the triclinic space groups $P 2_{1}$ and $P 2_{1} / \mathrm{m}$. It was later determined that the centrosymmetric space group $P 2_{1} / m$ was correct.

The structure was solved by direct methods and refined on $\mathrm{F}^{2}$ by full-matrix least-squares techniques. The analytical scattering factors ${ }^{\mathrm{S} 13}$ for neutral atoms were used throughout the analysis. Hydrogen atoms were included using a riding model. The THF ligand was disordered. Atoms C(13) and C(14) were included with partial site-occupancy-factors (1/2) to account for an equal distribution over two sites. At convergence, wR2 $=0.0746$ and GOF $=1.007$ for 159 variables refined against 2794 data. (As a comparison for refinement on $\mathrm{F}, \mathrm{R} 1=0.0323$ for those 2380 data with $\mathrm{I}>2.0 \sigma(\mathrm{I}))$. 


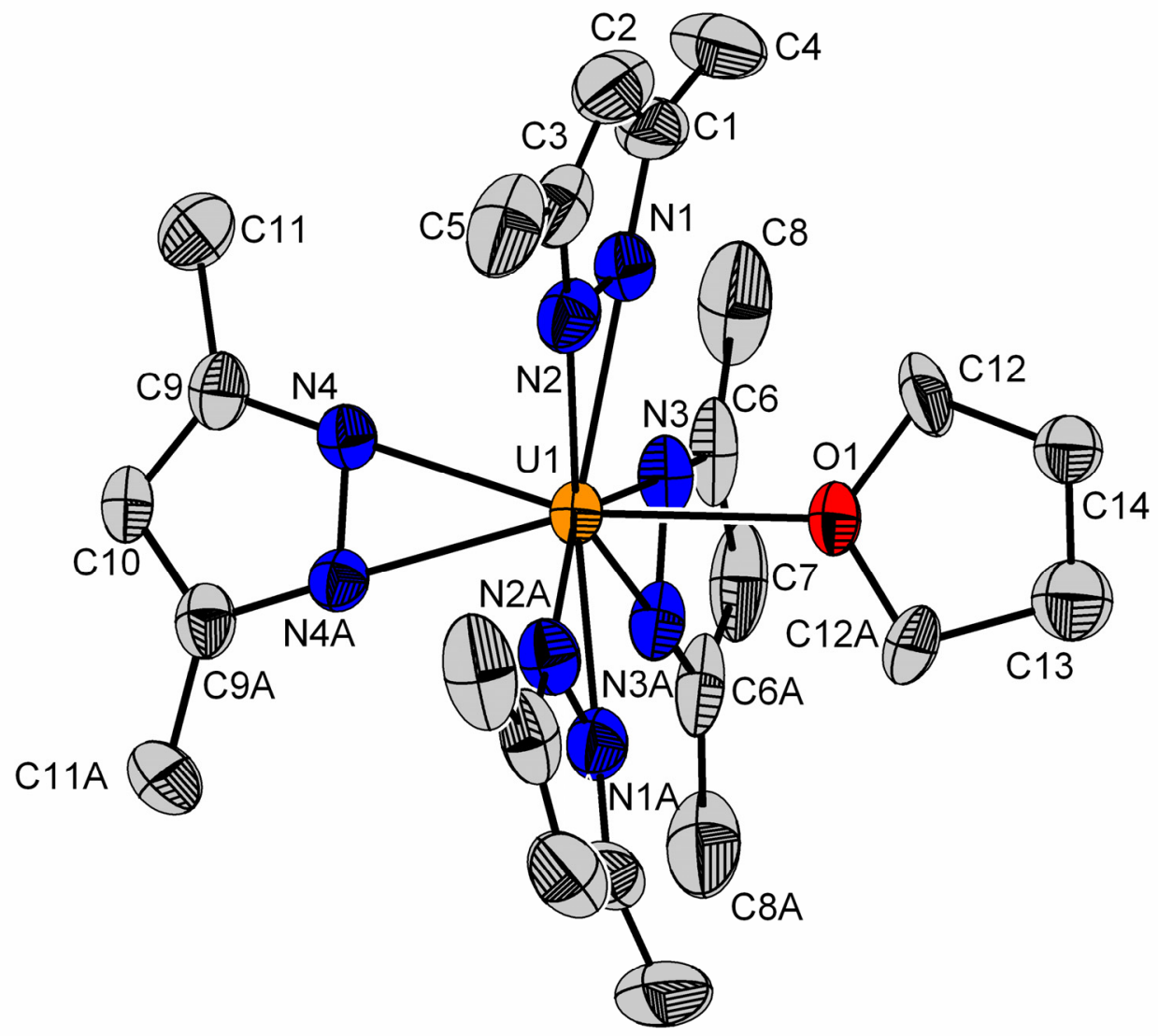

Figure S6. Structure of $\left(\mathrm{Me}_{2} \mathrm{Pz}\right)_{4} \mathrm{U}(\mathrm{THF})$ with ellipsoids drawn at the 50\% probability level. Orange, grey, blue, and red ellipsoids represent $\mathrm{U}, \mathrm{C}, \mathrm{N}$, and $\mathrm{O}$ atoms respectively; hydrogen atoms have been omitted for clarity. 
X-ray Data Collection, Structure Solution, and Refinement for $\left.\left(\mathrm{Me}_{2} \mathrm{Pz}\right)_{4} \mathrm{U}\right]_{2}(\mu$ Cl) ${ }_{2}[\mathrm{Ni}($ cyclam $)] \cdot \mathbf{4} \mathbf{C H}_{2} \mathbf{C l}_{2}$. A green crystal of approximate dimensions $0.20 \times 0.19 \times 0.04 \mathrm{~mm}$ was mounted on a Kapton loop and transferred to a Brüker SMART diffractometer and cooled in a dinitrogen stream. The $\mathrm{SMART}^{\mathrm{S} 9}$ program package was used to determine the unit-cell parameters and for data collection (10 s/frame scan time for a hemisphere of diffraction data). The raw frame data was processed using $\mathrm{SAINT}^{\mathrm{S} 10}$ and $\mathrm{SADABS}^{\mathrm{S} 11}$ to yield the reflection data file. Subsequent calculations were carried out using the SHELXTL ${ }^{\text {S12 }}$ program. The diffraction symmetry was $P \overline{1}$ and the systematic absences were consistent with the triclinic space groups $P 1$ and $P \overline{1}$. It was later determined that the centrosymmetric space group $P \overline{1}$ was correct.

The structure was solved by direct methods and refined on $F^{2}$ by full-matrix least-squares techniques. The analytical scattering factors ${ }^{\mathrm{S} 13}$ for neutral atoms were used throughout the analysis. Hydrogen atoms were included using a riding model. At convergence, $w R 2=0.1540$ and Goof $=1.067$ for 394 variables refined against 6158 data. As a comparison for refinement on $F, R 1=0.0482$ for those 5363 data with $\mathrm{I}>2.0 \sigma(\mathrm{I})$.

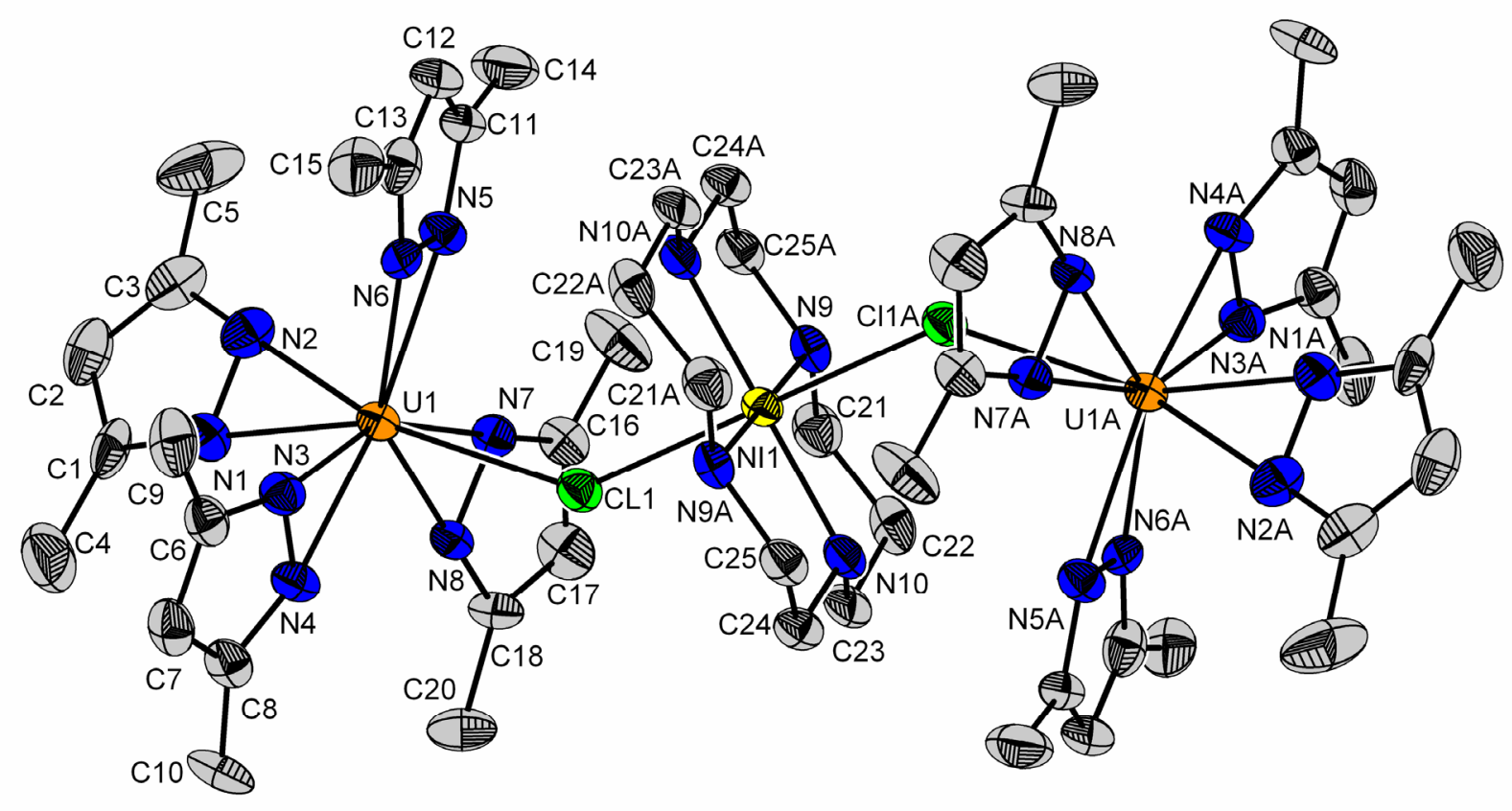

Figure S7. Structure of (cyclam) $\mathrm{Ni}\left[(\mu-\mathrm{Cl}) \mathrm{U}\left(\mathrm{Me}_{2} \mathrm{Pz}\right)_{4}\right]_{2}$ with ellipsoids drawn at the $50 \%$ level. Orange, grey, blue, green, and yellow ellipsoids represent $\mathrm{U}, \mathrm{C}, \mathrm{N}, \mathrm{Cl}$, and $\mathrm{Ni}$, atoms respectively; hydrogen atoms have been omitted for clarity. 


\section{X-ray Data Collection, Structure Solution, and Refinement for (cyclam)Cu[( $\mu$ -}

$\left.\mathbf{C l}) \mathbf{U}\left(\mathbf{M e}_{2} \mathbf{P z}\right)_{4}\right]_{2}{ }_{2} \mathbf{4 C H}_{2} \mathbf{C l}_{2}$. A light purple crystal of approximate dimensions $0.08 \times 0.08 \times 0.03$ mm was mounted on a Kapton loop and transferred to a Brüker SMART diffractometer. The SMART $^{\mathrm{S} 9}$ program package was used to determine the unit-cell parameters and for data collection (10 s/frame scan time for a hemisphere of diffraction data). The raw frame data was processed using SAINT $^{\mathrm{S} 10}$ and $\mathrm{SADABS}{ }^{\mathrm{S} 11}$ to yield the reflection data file. Subsequent calculations were carried out using the SHELXTL ${ }^{\mathrm{S} 12}$ program. The structure was solved in the centrosymmetric space group $P \overline{1}$.

The structure was solved by direct methods and refined on $\mathrm{F}^{2}$ by full-matrix least-squares techniques. The analytical scattering factors ${ }^{\mathrm{S} 13}$ for neutral atoms were used throughout the analysis. Hydrogen atoms were included using a riding model. The final least-squares analysis yielded $w R 2=0.1028$ and Goof $=0.997$ for 394 variables refined against 7516 data. As a comparison for refinement on $\mathrm{F}, \mathrm{R} 1=0.0472$ for those 5862 data with $\mathrm{I}>2.0 \sigma(\mathrm{I})$.

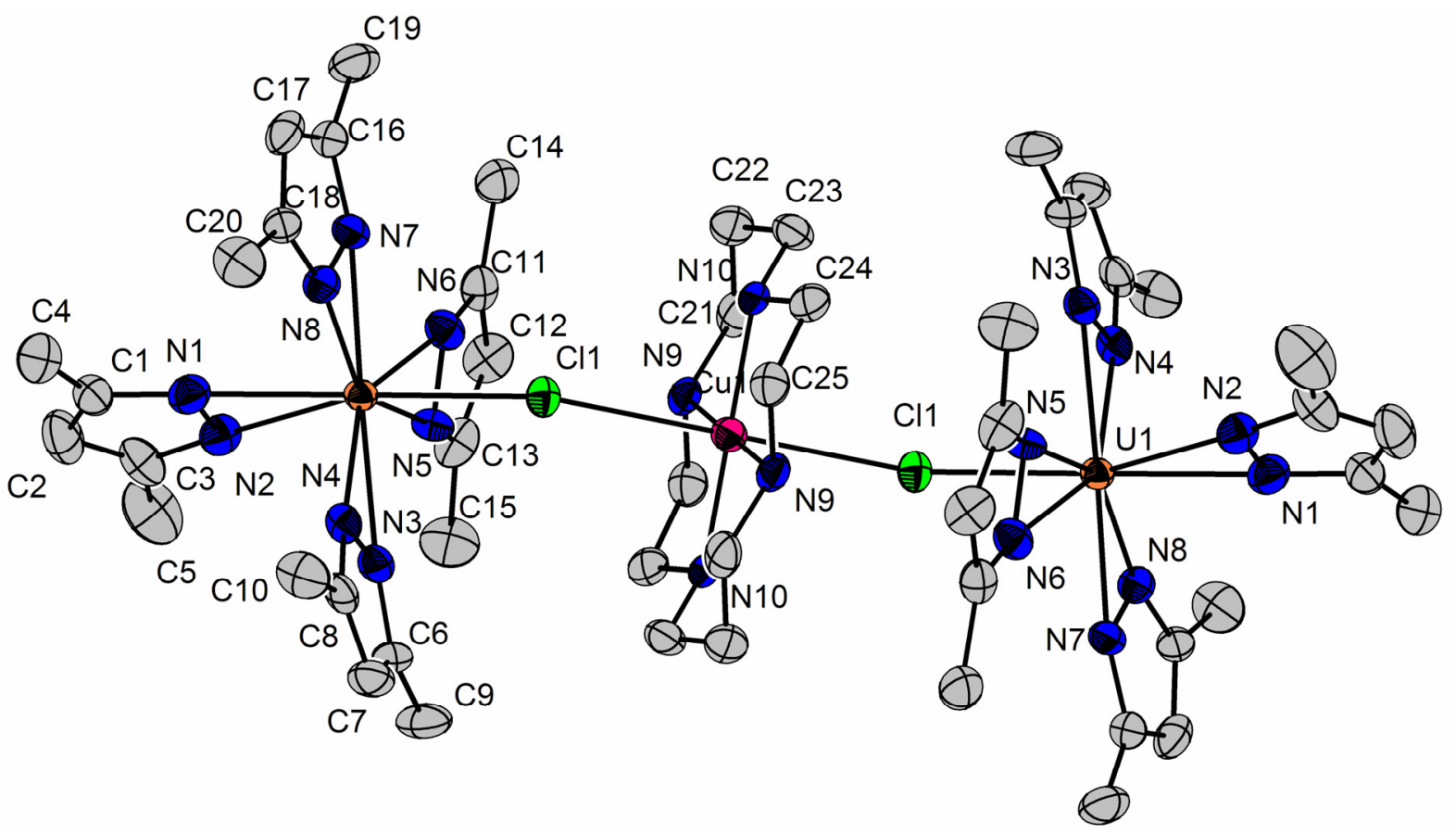

Figure S8. Structure of (cyclam $) \mathrm{Cu}\left[(\mu-\mathrm{Cl}) \mathrm{U}\left(\mathrm{Me}_{2} \mathrm{Pz}\right)_{4}\right]_{2}$ with ellipsoids drawn at the $50 \%$ probability level. Orange, grey, blue, green, and purple ellipsoids represent $\mathrm{U}, \mathrm{C}, \mathrm{N}, \mathrm{Cl}$, and $\mathrm{Cu}$, atoms respectively; hydrogen atoms have been omitted for clarity. 
X-ray Data Collection, Structure Solution, and Refinement for (cyclam)Zn $[(\mu$ $\left.\mathrm{Cl}) \mathrm{U}\left(\mathrm{Me}_{2} \mathbf{P z}\right)_{4}\right]_{2} \cdot \mathbf{4 C H}_{2} \mathbf{C l}_{2}$. A green crystal of approximate dimensions $0.06 \times 0.09 \times 0.22 \mathrm{~mm}$ was mounted on a Kapton loop and transferred to a Brüker SMART diffractometer and cooled in a dinitrogen stream. The $\mathrm{SMART}^{\mathrm{S} 9}$ program package was used to determine the unit-cell parameters and for data collection (10 s/frame scan time for a hemisphere of diffraction data). The raw frame data was processed using $\mathrm{SAINT}^{\mathrm{S} 10}$ and $\mathrm{SADABS}^{\mathrm{S} 11}$ to yield the reflection data file. Subsequent calculations were carried out using the SHELXTL ${ }^{\text {S12 }}$ program. The diffraction symmetry was $P \overline{1}$ and the systematic absences were consistent with the triclinic space groups $P 1$ and $P \overline{1}$. It was later determined that the centrosymmetric space group $P \overline{1}$ was correct.

The structure was solved by direct methods and refined on $\mathrm{F}^{2}$ by full-matrix least-squares techniques. The analytical scattering factors ${ }^{\mathrm{S} 13}$ for neutral atoms were used throughout the analysis. Hydrogen atoms were included using a riding model. At convergence, wR2 = 0.0941 and Goof $=1.041$ for 393 variables refined against 7272 data. As a comparison for refinement on $\mathrm{F}, \mathrm{R} 1=0.0420$ for those 5991 data with $\mathrm{I}>2.0 \sigma(\mathrm{I})$.

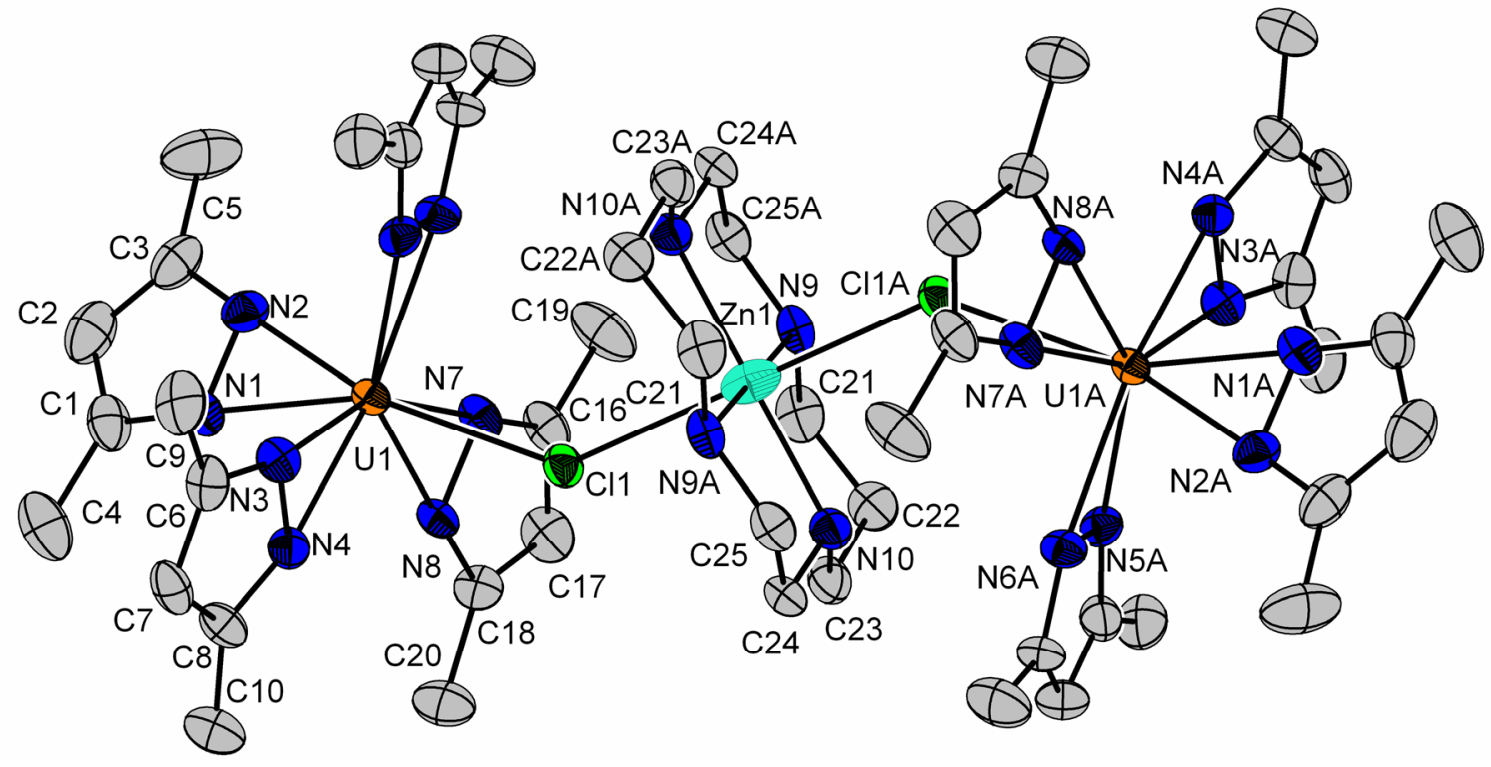

Figure S9. Structure of (cyclam) $\mathrm{Zn}\left[(\mu-\mathrm{Cl}) \mathrm{U}\left(\mathrm{Me}_{2} \mathrm{Pz}\right)_{4}\right]_{2}$ with ellipsoids drawn at the $50 \%$ probability level. Orange, grey, blue, green, and light blue ellipsoids represent $\mathrm{U}, \mathrm{C}, \mathrm{N}, \mathrm{Cl}$, and $\mathrm{Ni}$, atoms respectively; hydrogen atoms have been omitted for clarity. 


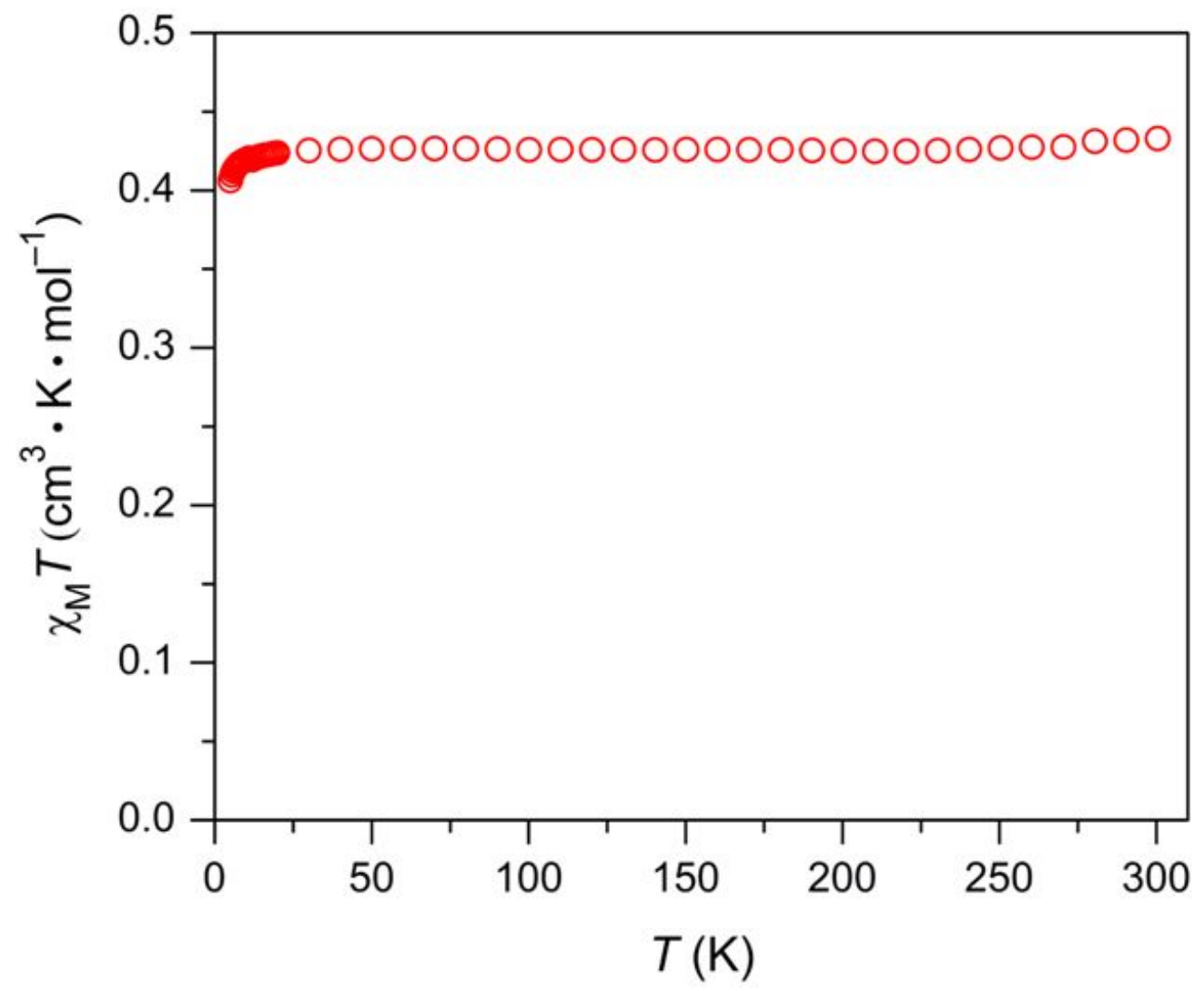

Figure S10. A plot of the $\chi_{\mathrm{M}} T$ data for (cyclam) $\mathrm{CuCl}_{2}$ vs. temperature, as measured in an applied field of 10,000 Oe. 


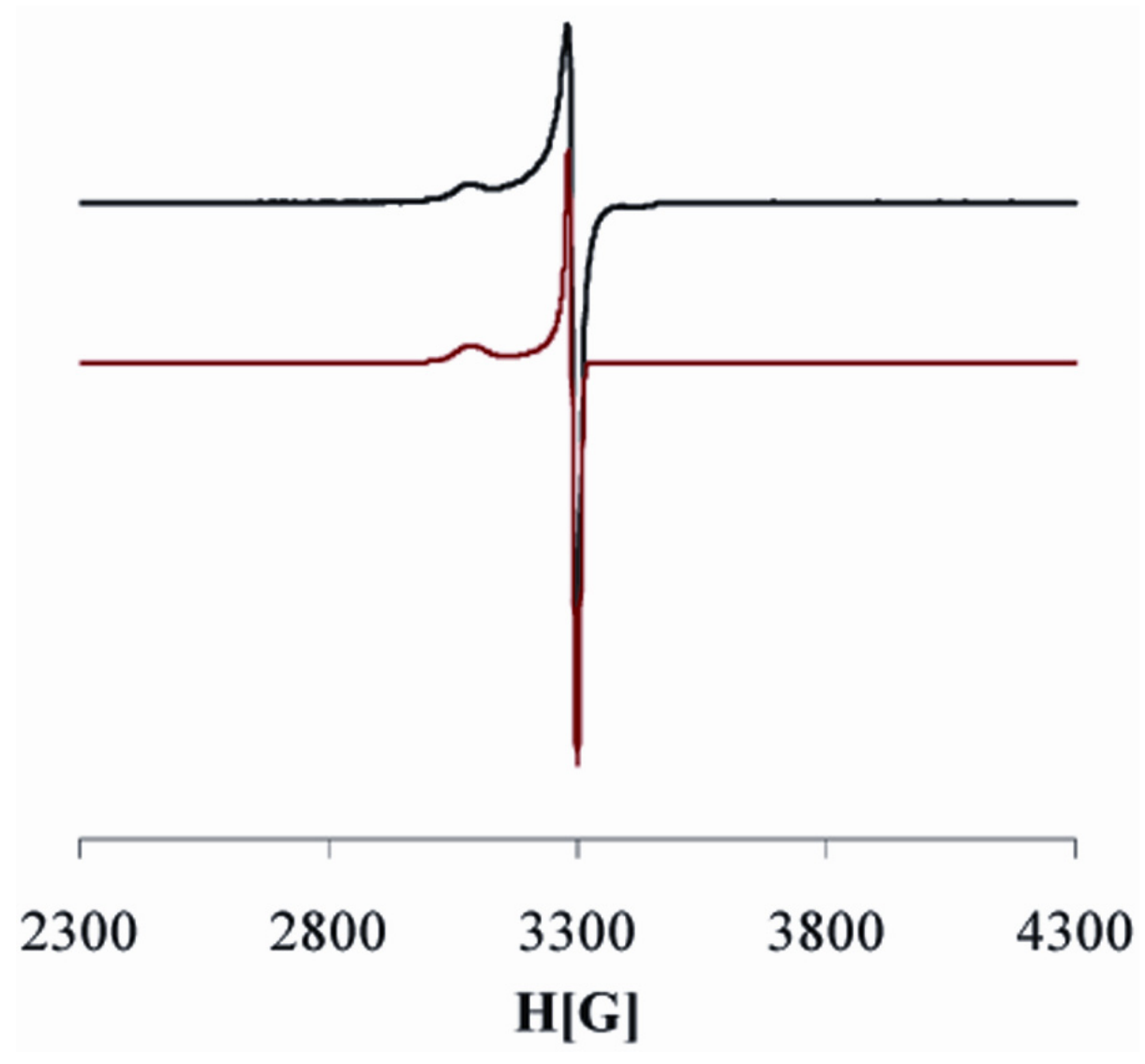

Figure S11. Experimental (black) and simulated (red) X-band EPR spectra for (cyclam) $\mathrm{CuCl}_{2}$ at $80 \mathrm{~K}$ in a frozen methanol solution. Experimental parameters: $9.451 \mathrm{GHz}, 63 \mu \mathrm{W}$. Simulation parameters: $g_{\perp}=2.05 ; g_{/ /}=2.19 ; A(\mathrm{Cu})_{\perp}=10 \mathrm{MHz} ; A(\mathrm{Cu})_{/ /}=25 \mathrm{MHz}$. 


\section{References}

(S1) Hermann, J. A.; Suttle, J. F.; Hoekstra, H. R. Inorg. Synth. 1957, 5, 143.

(S2) Bosnich, B.; Tobe, M. L.; Webb, G. A. Inorg. Chem. 1965, 4, 1109.

(S3) Bulach, V.; Mandon, D.; Fischer, J.; Weiss, R.; Bill, E.; Butzlaff, C.; Trautwein, A. X. New J. Chem. 1994, 18, 709.

(S4) Liang, X.; Weishäupl, M.; Parkinson, J. A.; Parsons, S.; McGregor, P. A.; Sadler, P. J. Chem. Eur. J. 2003, 9, 4709.

(S5) (a) te Velde, G.; Bickelhaupt, F. M.; van Gisbergen, S. J. A.; Guerra, C. F.; Baerends, E. J.; Snijders, J. G.; Ziegler, T. 'Chemistry with ADF', J. Comput. Chem. 2001, 22, 931. (b) Guerra, C. F.; Snijders, J. G.; te Velde, G.; Baerends, E. J. Theor. Chem. Acc. 1998, 99, 391. (c) ADF2006.01, SCM, Theoretical Chemistry, Vrije Universiteit, Amsterdam, The Netherlands, http://www.scm.com.

(S6) (a) van Lenthe, E.; Baerends, E. J.; Snijders, J. G. J. Chem. Phys. 1993, 99, 4597. (b) van Lenthe, E. Baerends, E. J.; Snijders, J. G. J. Chem. Phys. 1994, 101, 978. (c) van Lenthe, E.; Ehlers, A. E.; Baerends, E. J. J. Chem. Phys. 1999, 110, 8943.

(S7) Vosko, S. H.; Wilk, L.; Nusair, M. Can. J. Phys. 1980, 58, 1200.

(S8) Perdew, J. P.; Burke, K.; Ernzerhof, M. Phys. Rev. Lett. 1996, 77, 3865.

(S9) SMART Software Users Guide, Version 5.1, Bruker Analytical X-Ray Systems, Inc.; Madison, WI 1999.

(S10) SAINT Software Users Guide, Version 7.0, Bruker Analytical X-Ray Systems, Inc.; Madison, WI 1999.

(S11) Sheldrick, G. M. SADABS, Version 2.03, Bruker Analytical X-Ray Systems, Inc.; Madison, WI 2000.

(S12) Sheldrick, G. M. SHELXTL Version 6.12, Bruker Analytical X-Ray Systems, Inc.; Madison, WI 1999.

(S13) Internation Tables for X-Ray Crystallography, 1992, Vol.C., Dordrecht: Kluwer AcademicPubishers. 